\title{
Perspective Study of Exploring Some Medicinal Plants to Manage the Pandemic COVID-19
}

\author{
Ali A. A. Al-Shawi and Mustafa F. Hameed
}

\begin{abstract}
In the recent years, there was an increasing demand for discovering antiviral agents from medicinal plants having high activity and economically cheap. The medicinal plants have become very important because they have a main importance for determination, isolation and purification of natural chemical compounds in order to use them in many medicinal application. The scientific researches proved that plants extracts have antiviral activity against corona virus . The explanation of this activity belongs to presence of active chemical compounds act to stop the viruses in living body by multi different mechanisms. This review will provide an overview about the perspective of used some various medicinal plants against corona virus as antiviral drug and compared with antibiotics to reduce/prevent corona virus risk. In conclusion of this review, some medicinal herbs required urgent extensive work to develop natural antiviral agents to fight corona virus (COVID-19).
\end{abstract}

Index Terms - Angiotensin Conversion Enzyme 2, Andrographis paniculata, Camellia japonica, Corona virus COVID-19.

\section{INTRODUCTION}

Coronaviruses disease (COVID) belongs to a group of viruses which can cause infection to birds and mammals including human. According to world health organization , these viruses were responsible for many diseases and epidemic in worldwide, such as severe acute respiratory syndrome (SARS) in 2002-2003 and middle east respiratory syndrome (MERS) in South Korea republic in 2015 [1]. Recently, a new corona viruses have appeared (SARSCoV2) also represented by COVID-19 which has disappeared in China in December ,2019 [2]. Coronavirus-2 or SARS is severe acute respiratory syndrome and it briefly is known as SARS-CoV-2 [3], and it is also called COVID19 [4]. COVID-19 has reached to pathogenic stages in China and outside of China where it was found in the other twenty seven countries. On May, 2020, more than 4,982,875 cases were diagnosed for COVID-19 with 324,535 cases of death in the worldwide. In Iraq, to date more than 3600 cases of coronavirus, 2366 recovered and 131 death and the virus infections are continued due the unobligated people with advices of ministry of health. Current therapies and vaccines have not yet developed and still ongoing. Therefore, many countries infected by this virus, have done various proceedings such as distraction of traveling,

Published on July 16, 2020

Ali A. A. Al-Shawi, Chemistry Department, College of Education for Pure Sciences, University of Basrah, Iraq.

(corresponding e-mail: : ali.abdulhussein ${ }^{@}$ uobasrah.edu.iq)

Mustafa F. Hameed, Ministry of Education, Basrah Education Directorate, Iraq. isolation of patients and continuous medical care to reduce and prevent coronavirus spreading [5]. The transfer average of COVID-19 is more than SARS 1 because of occurrence of rearrangement in the genetic structure of protein $S$ in position of binding with receptor-binding domain (RBD) for COVID-19, so this statement has increased for its ability to transfer among humans with very high velocity [6]. The corona virus use spike proteins for iterance in target cell where spike proteins binds with cellular receptor ACE2 (Angiotensin Conversion Enzyme 2) to facilitate viral blinding on the surface of target cell in order to permit the COVID-19 to inter into cells. Spike proteins must be prepared by an enzyme present on surface of target cell, called TMPRSS2 (Transmembrane Serine Protease 2) for completed of process of interface of virus into cell [7]. Fig 1 showed the binding of COVID-19 with alveoli (air vesicles) and the viral genome is liberated in the cytoplasm of target cell where this genome as mRNA (messenger ribonucleic acid ) and the cell ribosome translates the di-genome then RNA polymerase enzyme acts to replicate RNA genome directly to form other gnomes and anabolism of RNA molecules are special for viral proteins [8].

\section{MEDICINAL HERBS USED FOR CORONA VIRUSES}

Medicinal herbs were used against different diseases including viral diseases and these herbs have become an essential purpose to determine, isolate and purify the natural compounds for treatment of viral diseases such as viral hepatic inflammatory [9]. There are 25\% of known compounds were isolated from originally medicinal herbs used in the medication, such as Aspirin drug from Salix alba used to reduce pain and fever or inflammation, Coumadin drug from Medicago sative which used as anticlotting, and quinine drug from Cinchona officinalis as antimalarial [10]. The activity of medicinal herbs belongs to the second metabolism bioactive compounds such as flavonoids, phenols, tannins, terpenes, alkaloids, glycosides, coumarins, saponins and steroids, which can inhibit the growth of various viruses by acting with RNA and DNA [11]. Therefore, these naturally bioactive compounds have medical value as therapies against functionally and genetically variety viruses [12], such as coated and noncoated virus also against stains or types of various viruses [13], [14]. There are attempts to development of active drugs against COVID-19 according to their different mechanism, for example ACE2 antibodies can be used to prevent binding of COVID-19 with receptor. In addition, TMPRSS2 inhibitors can be carried out for prevention of intrance of the virus into the host cells [15]. Many studies indicated that many bioactive compounds of medicinal herbs 
have showed antiviral activity against coronavirus, and the mechanism of action was via inhibition of viral transcription [16].

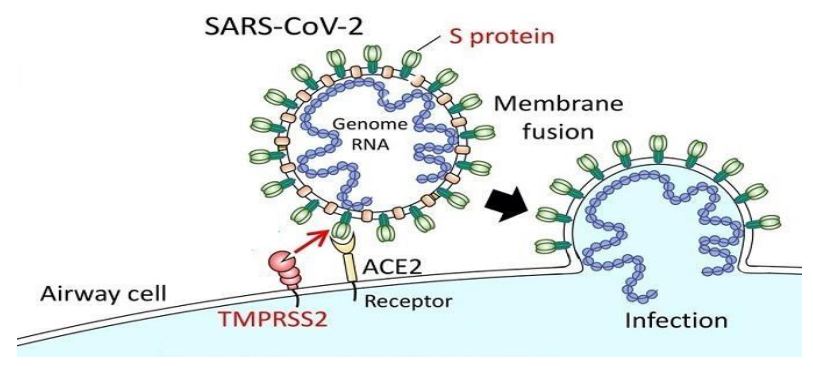

Fig 1. Binding of COVID-19 with ACE2. coronavirus enzyme or inhibition factors of anabolism of protein belonging to virus, for example : methanolic extracts of Sophora subprostrata leaves, Cimicifuga rhizome fruits and Phellodendron cortex showed antiviral activity for growth of coronavirus (mice hepatic inflammatory-MHV) [17]. The mechanism against this virus depend on inhibition of RNA replication, and these herbs extracts could inhibit anabolism of $\mathrm{N}$ and $\mathrm{S}$ protein [18]. In addition, the aqueous extract of Houttuynia cordata leaves has many mechanisms against SARS-CoV virus, such as inhibition of viral protein enzyme (3CLpro) and inhibition of activity of RNA polymerase then stop and end the spreading of virus and disappear in human body [19].

Moreover, some plant extracts were used as inhibitors of
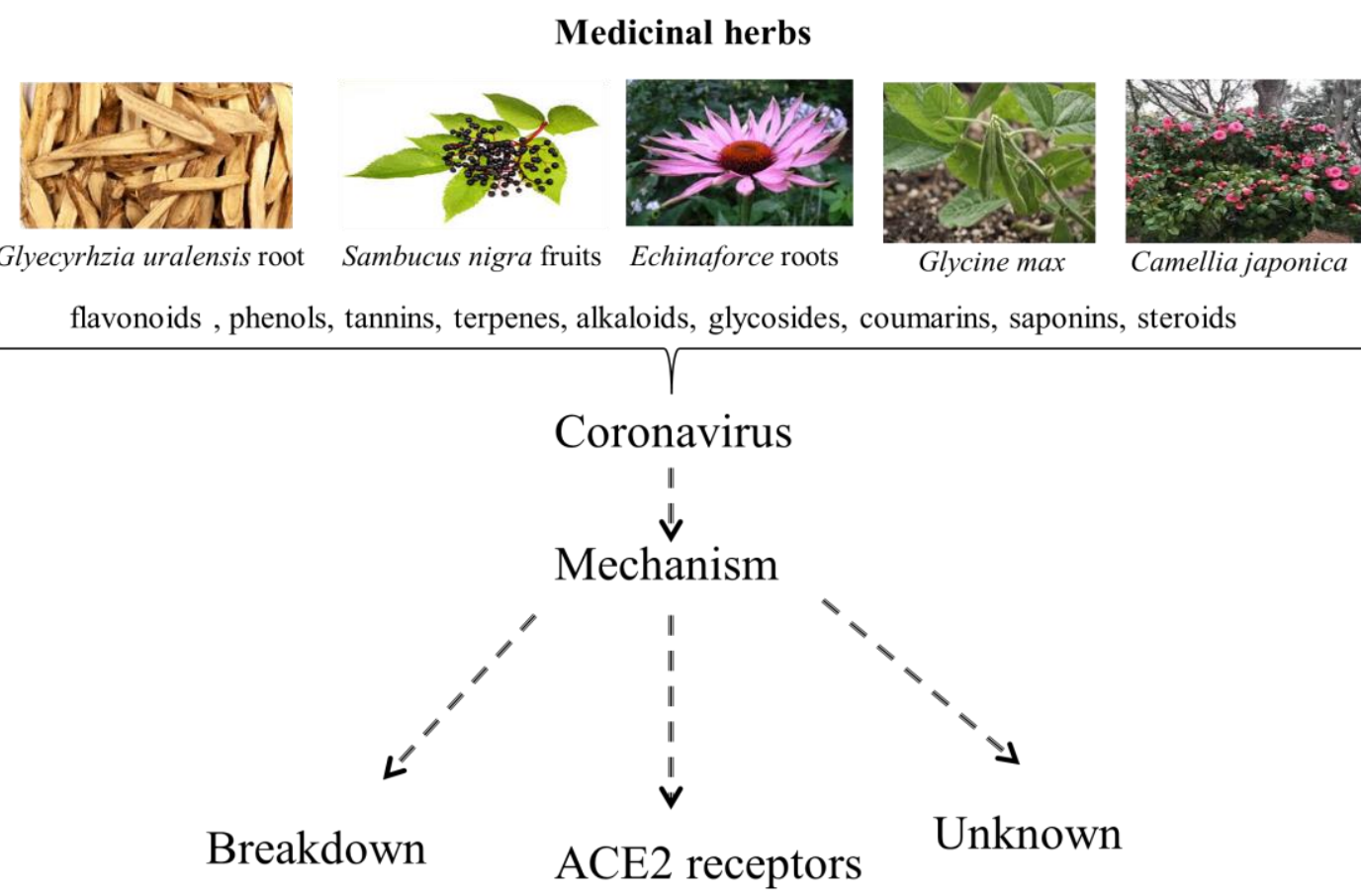

Fig 2. Some medicinal plants used against corona virus.

\section{THE POSSIBLE MECHANISMS OF MEDICINAL HERBS AND CORONAVIRUS INTERACTION}

To control the spreading of coronavirus infections, should understand the structure of virus and RNA replication. Several studies have been shown the possible mechanism of preventing coronavirus spreading used medicinal herbs. Cinatl and his group showed that the chemical compound glycyrrhzin (Fig. 3) was isolated from Glyecyrhzia uralensis root has a high activity against SARS-CoV virus and this compound could stop growth of this virus completely at concentration (4 mglml). The mechanism of this compound against SARS1 is not clear and it is thought that because of effect on transcription agent and cellular signals pathways such as carrier protein C and carrier casein [20]. Chen and his group showed that ethanolic extract of Sambucus nigra fruits breakdowns directly the shell belonging to composition of coronavirus (Infectious bronchitis virus IBV) or may be destruct the shell completely or maybe because of it contains polyphenols [21]. Yang and his group isolated fifteen terpenes from Camellia japonica flowers, thirteen coumarin derivatives (Fig. 3) from Saposhnikovia divaricata roots and four phenolic from Dryopteris crassirhizoma roots, and all these compounds showed excellent activity for growth inhibition growth of coronavirus (Porcine epidemic diarrhea virus PEDV) by mechanism of inhibition of skeleton protein of coronavirus (PEDV) then inhibition of viral growth [22]. Signer and his group showed that ethanolic extract of Echinaforce roots has antiviral activity against human coronavirus 229E and severe coronaviruses (Middle East respiratory syndrome MERS and SARS1), the breakdown of coronavirus HCoV$229 \mathrm{E}$ depends on the dose of this extract also $50 \%$ of growth of this virus decreased at concentration of $3.2 \mu \mathrm{g} / \mathrm{ml}$ then this extract can be used as protective therapy against a big group of coronaviruses which infect the respiratory system leading to find protective drugs has cheap cost against all coronaviruses [23]. $\mathrm{Li}$ and his group showed that the alkaloidic compound named lycorine (Fig 3) isolated from L. radiate herb has an excellent activity against SARS1 virus where the cytotoxic concentration $50\left(\mathrm{CC}_{50}\right)$ to virus is $1498 \mathrm{nM}$ and the moderate effective concentration $\left(\mathrm{EC}_{50}\right)$ is $15.7 \mathrm{nM}$ [24]. Furthermore, the development of vaccine depending on spike protein is explained by fact that ACE2 is 
receptor for COVID-19, where there are three types of viral inhibitors into host cell, the first is inhibitors of ACE2 receptor which prevent binding with virus but the second type is considered as inhibitors bind with virus and prevent it to react with ACE2 receptors whereas the third type of inhibitors breakdown formation changes during binding between receptor and virus [25]. An example of first type inhibitors is represented by the chemical compound nicotianamine (Fig. 3) abundant in Glycine max [26]. This compound shows a great inhibition for ACE2 enzyme with value $\mathrm{IC}_{50}$ equal to $84 \mathrm{nM}$. It may be prevent contagion or infection COVID-19 by inhibition of ACE2 enzyme and this explanation needs further laboratory clinical studies [27]. Emodin is the second type of inhibitors which have many uses among medical media where these inhibitors bind with ACE2 receptors. Emodin compound is belong to anthraquinone class and one of the main components of Rheum roots and Polygonum species. Emodin inhibits the activity of proteins $S$ belonging to virus SARS1 then prevents binding with ACE2 receptor with procedure depends on increase of dose leading to finish the biological role of SARS1 virus in human body [28]. Also the Hydroxy Chloroquine and Promazine compounds act by the same mechanism of Emodin (Fig. 3).<smiles>CN(C)CCCN1c2ccccc2Sc2ccccc21</smiles>

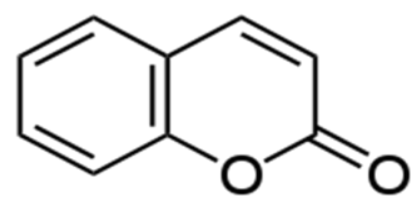

Coumarin<smiles>Cc1cc(O)c2c(c1)C(=O)c1cc(O)cc(O)c1C2=O</smiles>

Promazine

\section{Emodin}<smiles>CC(=O)O[C@@H]1[C@@H]2[C@H]3C(=C[C@H](O)[C@H]1O)CCN2Cc1cc2c(cc13)OCO2</smiles>

Lycorine<smiles>N[C@@H](CCN[C@@H](CCN1CC[C@H]1C(=O)O)C(=O)O)C(=O)O</smiles>

Nicotianamine<smiles>CCN(CC)CCCC(C)Nc1ccnc2cc(Cl)ccc12</smiles>

Chloroquine

Fig 3. The chemical structure of some bioactive compounds isolated from medicinal herbs used in corona virus studies.

The possibility of using lycorine compound against COVID-19 virus because of the high similarity between the two coronaviruses. Therefore, the first step is to determine the interaction of lycorine with COVID-19 through docking studies to approve the efficacy of lycorine, whether could be use in prevent COVID-19. On the other hands, the inhibitor binding with virus and prevent it to react with ACE2, can be produced, purified and characterized such as emodin compound which existing in plants belonging Polygonum species. Likewise, the compounds hydroxy Chloroquine in Andrographis paniculata leaves and Nicotianamine compound in Glycine max plant plays as inhibitors of ACE2 receptor and prevention of binding with virus, where these inhibitors have an essential role for stopping the growth and replication of COVID-19 virus in human body [32]. Moreover, Vellingiri and his group suggested that Indian medicinal herbs could be used as good source for possible therapeutic targeting SARS-CoV-2 [33]. In addition, a human clinical trial study based on used fifteen antiviral drug against ten isolated SARS corona virus patients. Among the antiviral drugs, there was three chemical compounds isolated from Chinese medicinal herbs (baicalin, glycyrrhizin, and chlorogenic acid), the results showed that baicalin was less expensive and could be use for corona virus treatment [34]. Another Chinese clinical study used the medicinal herbs named Qingfei Paidu Decoction (QFPD) to treat COVID-19 patients and found it attributed the antiinflammatory effects of Ma Xing Shi Gan Decoction associated with QFPD which they enhanced traditional Chinese medicine role in treatment of COVID-19 [35]. Thus, Glycyrrhizin may induced COVID-19 via block the number of entry points and also provide an ACE2 independent anti-inflammatory mechanism [36]. Glycyrrhetinic acid is metabolite from glycyrrhizin and showed potent action against two new human herpes viruses HHV-6 and HHV-7, hepatitis A, B, and C viruses (HAV, $\mathrm{HBV}, \mathrm{HCV}$ ) [37]. Chlorogenic acid used to reduce serum hepatitis B virus level and death rate of influenza virusinfected mice and acts as a neuraminidase blocker to inhibit influenza A virus both in cellular and animal models [38], as shown in Fig 4.

In conclusion of this review, traditional medicinal herbs (Chinese herbs, Indian herbs, Iraqian herbs, etc) are supporting human immune system and continue in fighting corona virus. Many natural molecules isolated from medicinal herbs with varies biological activities could be used in reduce of COVID-19 risk or designing novel antiviral drugs. Thus, recommended an extensive studies to evaluate some of medicinal plants extracts or bioactive compounds and discover new medicinal plants to prevent and reduce the risk of pandemic corona virus (COVID-19). 


\section{Baicalin}<smiles>O=C(O)[C@H]1O[C@@H](Oc2cc3oc(-c4ccccc4)cc(=O)c3c(O)c2O)[C@H](O)[C@@H](O)[C@@H]1O</smiles>

Toll-like receptor signaling pathway
Glycyrrhizin

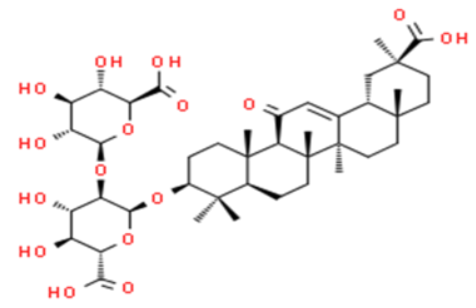

1. To block the number of entry points.

2. provide an ACE2 independent antiinflammatory mechanism
Chlorogenic acid<smiles>O=C(/C=C/c1ccc(O)c(O)c1)O[C@@H]1C[C@@](O)(C(=O)O)C[C@H](O)[C@H]1O</smiles>

Acts as a neuraminidase blocker to inhibit influenza A virus both in cellular and animal models
1. Inhibits 11beta hydroxysteroid dehydrogenase (11betaHSD2)

2. Activates MR in organs

3. potent inhibitor of Herpes simplex virus type 1 (HSV-1)

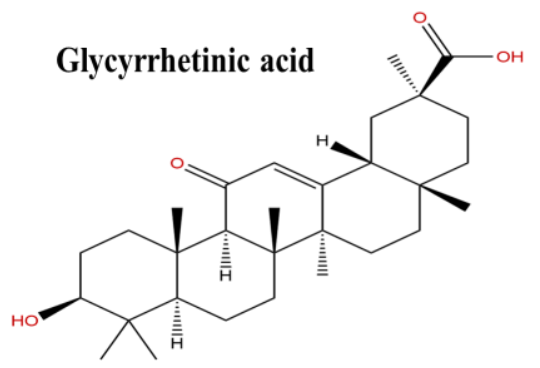

Fig 4. The chemical structure of some bioactive compounds isolated from traditional Chinese medicine and mechanism of action against viruses.

\section{REFERENCES}

[1] Kenneth M, Martin S, Allyson B. Coronavirus disease 2019 (COVID19): Epidemiology, virology, clinical features, diagnosis, and prevention. Literature review current through: This topic last updated: Apr 28, 2020.

https://www.uptodate.com/contents/coronavirus-disease-2019-covid19-epidemiology-virology-clinical-features-diagnosis-and-prevention.

[2] Marco C, Michael R, Arturo C, Scott C, Raffaela D. Features, Evaluation and Treatment Coronavirus (COVID-19). StatPearls Publishing LLC. Bookshelf ID: NBK554776, 2020. PMID: 3215036.

[3] Alexander E, Susan C, Ralph S, Raoul J, Christian D, Anastasia A, Bart L. The species Severe acute respiratory syndrome-related coronavirus: classifying 2019-nCoV and naming it SARS-CoV-2. Nat Microbi. 2020; 5: 536-544. https://doi.org/10.1038/s41564-020-0695-

[4] World Health Organization. Surveillance case definitions for human infection with novel coronavir ( $\mathrm{nCoV})$ : interim guidance v1, January 2020 (No. WHO/2019-nCoV/ Surveillance /v2020. 1). World Health Organization.

[5] Ahn D, Shin H, Kim M, Lee S, Kim H, Myoung J, Kim B, Kim S. Current Status of Epidemiology, Diagnosis, Therapeutics, and Vaccines for Novel Coronavirus Disease 2019 (COVID-19). J Microbiol Biotechnol. 2020;30 (3): 313-324. https://doi.org/ 10.4014/jmb.2003.0301.

[6] Shereen M, Khan S, Kazmi A, Bashir N, Siddique R. COVID-19 infection: origin, transmission, and characteristics of human coronaviruses. J Adv Res. 2020; 16: 24 : 91-98. https://doi.org/10.1016/j.jare.2020.03.005.

[7] Hoffmann H, Kleine W, Schroeder S, Krüger N, Herrler T, Erichsen S. SARS-CoV-2 cell entry depends on ACE2 and TMPRSS 2 and is blocked by a clinically proven protease inhibitor. $\begin{array}{llll}\text { Cell. 2020;181 } & \text { (2): }\end{array}$ https://doi.org/10.1016/j.cell.2020.02.052.

[8] Helena J, Erica B, Paul B. Coronaviruses: Methods and Protocols, Methods in Molecular Biology, vol. 1282, Chapter 1. Springer Science+Business Media New York, 2015 https://doi.org/ 10.1007/978-1-4939-2438-7_1.

[9] Dhama K, Karthik K, Khandia R, Munjal A, Tiwari R, Rana R. Medicinal and Therapeutic Potential of Herbs and Plant Metabolites / Extracts Countering Viral Pathogen - Current Knowledge and Future Prospects. Curr Drug Metab. 2018; 19 (3) : 236 - 263. https://doi.org/10.2174/138920021966618012914525.
[10] Kinghorn AD. The discovery of drugs from higher plants. Biotechnolo. 1994; 26: 81-108. https://doi.org/10.1016/b9780-7506-9003-4.50010-1.

[11] Akram M, Tahir I, Shah S, Mahmood Z, Altaf A, Ahmad K, Munir N, Daniyal M, Nasir S, Mehboob H. Antiviral potential of medicinal plants against HIV, HSV, influenza, hepatitis, and coxsackievirus: A systematic review. Phytother Res. 2018; 32 (5): 811-822. https://doi.org/ 10.1002/ptr.6024.

[12] Jassim S, Naji M. Novel antiviral agents: a medicinal plant perspective. J Appl Microbi. 2003; 95: 412-427 https://doi.org/10.1046/j.1365-2672.2003.02026.x.

[13] Visintini J, Redko F, Muschietti L, Campos R, Martino V, Cavallaro L. In vitro antiviral activity of plant extracts from Asteraceae medicinal plants. Virol J. 2013; 10: 245. https://doi.org/10.1186/1743-422X-10-245.

[14] Schuhmacher A, Reichling J, Schnitzler P. Virucidal effect of peppermint oil on the enveloped viruses herpes simplex virus type 1 and type 2 in vitro. Phytomedicine. 2003; 10: 504-10. https://doi.org/10.1078/094471103322331467.

[15] Heurich A, Hofmann W, Gierer S, Liepold T, Jahn O, Pöhlmann S. TMPRSS2 and ADAM17 cleave ACE2 differentially and only proteolysis by TMPRSS2 augments entry driven by the severe acute respiratory syndrome coronavirus spike protein. J Virol. 2014; 88(2): 1293-307. https://doi.org/10.1128/JVI.02202-13.

[16] Kim H, Eo E, Park H, Kim Y, Park S, Shin H, Kim K. Medicinal herbal extracts of Sophorae radix, Acanthopanacis cortex, Sanguisorbae radix and Torilis fructus inhibit coronavirus replication in vitro. Antivir Ther. 2010; 15(5): 697-709. https://doi.org/10.3851/IMP1615.

[17] Kim H, Shin S, Park H, Kim Y, Yun Y, Park S, Kim K. In vitro inhibition of coronavir replications by the traditionally used medicinal herbal extracts, Cimicifuga rhizoma, Meliae cortex, Coptidis rhizoma, and Phellodendron cortex. J clinical virolo. 2008; 41(2): 122-128. https://doi.org/10.1016/j.jcv.2007.10.011.

[18] Ruffa M, Wagner M, Suriano M, Vicente C, Nadinic J, Pampuro S, Salomón H, Campos R, Cavallaro L. Inhibitory effect of medicinal herbs against RNA and DNA viruses. Antivir Chem Chemother. 2004; 15(3):153-9. https://doi.org/10.1177/095632020401500305.

[19] Lau K, Lee K, Koon C, Cheung C, Lau C, Ho H. Immunomodulatory and anti-SARS activities of Houttuynia cordata. J Ethnopharmac. 2008; 118: 79-85. https://doi.org/10.1016/j.jep.2008.03.018

[20] Cinatl J, Morgenstern B, Bauer G, Chandra P, Rabenau H, Doerr H. Glycyrrhizin, component of liquorice roots, and replication of SARS- 
associated coronavirus. Lancet. 2003; (9374): 2045-6631. https://doi.org/10.1016/s0140-6736(03)13615-x.

[21] Chen C., Zuckerman D, Brantley S, Sharpe M, Childress K, Hoiczyk E, Pendleton A. Sambucus nigra extracts inhibit infectious bronchitis virus at an early point during replication. BMC Vet Res. 2014; 16: 10:24. https://doi.org/10.1186/1746-6148-10-24.

[22] Yang L, Ha T, Oh W. Discovery of inhibitory materials against PEDV corona virus from medicinal plants. Japanese J Veterinary Resea. 2016; 64(Supplement 1): S53-S63. https://doi.org/10.14943/jjvr.64.suppl.s53.

[23] Signer J, Jonsdottir H, Albrich W. In vitro antiviral activity of Echinaforce $\AA$, an Echinac purpurea preparation, against common cold coronavirus $229 \mathrm{E}$ and highly pathogenic MERS-CoV and SARSCoV. J Virol. 2020 . https://doi.org/10.21203/rs.2.24724/v.

[24] 24. Li S, Chen C, Zhang H, Guo H, Wang H, Wang L, Li R. Identification of natural compounds with antiviral activities against SARS-associated coronavirus. Antiviral Res. 2005; 67(1): 18-23. https://doi.org/ 10.1016/j.antiviral.2005.02.007.

[25] Zhang H, Penninger J, LiY, Zhong N, Slutsky A. Angiotensinconverting enzyme 2 (ACE2) as a SARS-CoV-2 receptor: molecular mechanisms and potential therapeutic target. Intensive Care Med. 2020; 46(4): 586-590. https://doi.org/ 10.1007/s00134-020-05985-9.

[26] 26. Keyaerts E, Vijgen L, Pannecouque C, Van Damme E, Peumans W, Egberink Ranst M. Plant lectins are potent inhibitors of coronaviruses by interfering with two targets in the viral replication $\begin{array}{llll}\text { cycle. Antiviral } & \text { Res. } & 2007 ; & 75(3):\end{array}$ https://doi.org/10.1016/j.antiviral.2007.03.003.

[27] Takenaka T. Isolation of Nicotianamine from Soybean Broth and Antihypertensive Effects Spontaneously Hypertensive Rats. J Bre. Soc. JAPAN. 2009; 104(11): 858-865. https://doi.org/10.6013/jbrewsocjapan.104.858.

[28] Takahashi S, Yoshiya T, Yoshizawa K, Sugiyama T. Nicotianamine is a novel angiotensin-converting enzyme 2 inhibitor in soybean. Biomed Res. 2015; 36(3): 219-24. https://doi.org/ 10.2220/biomedres.36.219.

[29] Ho T, Wu S, Chen J, Li C, Hsiang C. Emodin blocks the SARS coronavirus spike protein and angiotensin-converting enzyme 2 interaction. Antiviral Res. 2007; 74(2): 92-101. https://doi.org/10.1016/j.antiviral.2006.04.014.

[30] Luis E, Marta L, Enrique A, Damon D, Tim S, Ralph B. Vaccines to prevent severe acute respiratory syndrome coronavirusinduced $\begin{array}{llll}\text { disease. } & \text { Virus } & \text { Res. 2008; 133(1): }\end{array}$ https://doi.org/10.1016/j.virusres.2007.01.021.

[31] Paul A, Steven O., Stephan S., Allan N., Ray C., Joseph P. Characterization of a novel coronavirus associated with severe acute $\begin{array}{lll}\text { respiratory } & \text { syndrome. } & \text { Science. 2003; } 300(5624): 1394-9\end{array}$ https://doi.org/10.1126/science.1085952.

[32] Uzor P, Prasasty V, Agubata C. Natural Products as Sources of Antimalarial Drugs. Evid Base Complement Alternat Med. 2002; 2020: 9385125. https://doi.org/10.1155/2020/9385125.

[33] Vellingiri B, Jayaramayya K, Iyer M, Narayanasamy A, Govindasamy V, Giridharan B, Ganesan S, Venugopal A, Venkatesan D, Ganesan H, Rajagopalan K, Rahman PKSM, Cho SG, Kumar NS, Subramaniam MD. COVID-19: A Promising Cure for the Global Panic. Sci Total Environ. 2020; 725: 138277. https://doi.org/ 10.1016/j.scitotenv.2020.138277.

[34] Chen F, Chan K, Jiang Y, Kao R, Lu H, Fan K, Cheng V, Tsui W, Hung I, Lee T, Guan Y, Peiris J, Yuen K. In vitro susceptibility of 10 clinical isolates of SARS coronavirus to selected antiviral compounds. J Clini $\quad$ Virol. 2004; 31(1): 69-75. https://doi.org/10.1016/j.jcv.2004.03.003.

[35] Ruocong Y, Hao L, Chen B, Yingchao W, Xiaohui Z, Rui G, Siying W, Jianxun W, Elaine L, Hang C, Peng L, Tiegang L, Yi W. Chemical Composition and Pharmacological Mechanism of Qingfei Paidu Decoction and Ma Xing Shi Gan Decoction Against Coronavirus Disease 2019 (COVID-19): In Silico and Experimental Study. Pharmacol Res 2020; 157: 104820. https://doi.org/10.1016/j.phrs.2020.104820.

[36] Harald M. Symptomatic Protective Action of Glycyrrhizin (Licorice) in COVID-19 Infection?. Front Immunol. 2020; 11:1239. https://doi.org/10.3389/fimmu.2020.01239.

[37] Baltina LA, Kondratenko RM, Baltina J, Plyasunova OA, Pokrovskii AG, Tolstikov GA. Prospects for the Creation of New Antiviral Drugs Based on Glycyrrhizic Acid and Its Derivatives (A Review). Pharm Chem J. 2009; 43(10): 539-548. https://doi.org/ 10.1007/s11094-010-0348-2.

[38] Yue D, Zeyu C, Liang C, Gang D, Zhengzhong W, Wei X. Antiviral Activity of Chlorogenic Acid Against Influenza A (H1N1/H3N2) Virus and Its Inhibition of Neuraminidase. Sci Rep. $2017 ; 7$ : 45723. https://doi.org/ 10.1038/srep45723. 